PONCiano Del Pino

\title{
En nombre del gobierno. El Perú y Uchuraccay: un siglo de política campesina
}

Lima: La Siniestra Ensayos, Universidad Nacional de Juliaca, 2017

Cuando Uchuraccay es citado inevitable se hace recurrir al recuerdo de las fotografías blanquinegras de la tarde del 26 de enero de 1983. Son estas imágenes acompañadas de un discurso monótono las que proliferan tribunas periodísticas evocando la matanza en esta comunidad, que a la par que condenan el Informe de la Comisión Investigadora reproducen sus sesgos de manera simulada, previsiblemente refiriendo "una memoria" estancada en el tiempo, de arcaicos comuneros dispuestos a la confusión de lo "moderno", invariable de los sucesos o posiciones que motivan el recuerdo.

Es así que En nombre del gobierno. El Perú y Uchuraccay: un siglo de política campesina brinda un giro importante en el análisis acerca de la construcción de las memorias, es decir en el patrón de recuerdo, abordándolas históricamente. Buscando comprender las condiciones históricas y políticas concretas en la formación de recuerdos y silencios de la violencia: 1) el contexto de deterioro institucional y de conflictos intracomunales, tomando como estudio de caso la comunidad de Uchuraccay, para cuando el PCP-SL irrumpe, generado por la "pérdida del respeto" hacia la soberanía de la autoridad comunal producto de restringir la vida comunal al orden económico-productivo con la Reforma Agraria velasquista; y 2) el patrón de recuerdo público en las comunidades que moldean sus posiciones y acciones, de lo que es narrado y lo que no en pro de la estabilidad de autoridad, gobernabilidad y convivencia en la (re)fundación de Uchuraccay una década después de la matanza.

El libro aborda las memorias de la violencia y sus dinámicas de lucha en un más grande espacio de memorias largas constituido por el peregrinaje político en busca del gobierno de la primera mitad del siglo Xx, de su "amparo" y "protección" por el reconocimiento "inmemorial" de sus tierras comunales, emergiendo la legitimidad de esas acciones desde la memoria y la identidad.

La radical importancia de esta investigación etnográfica e histórica es que escapa al panorama de confrontación y radicalidad entre el Estado y las comunidades en cuyos estudios los aspectos estructurales resultan determinantes para la explosión de la insurgencia armada como lo expone Degregori en El surgimiento de Sendero Luminoso. Sino más bien, advierte articulaciones latentes entre estas producto de la búsqueda del reconocimiento de los márgenes, como son la llegada a la Dirección de Asuntos Indígenas - la cual no ofrecía garantías reales de protección- de dirigentes comunales 
haciéndole frente a la "ley del hacendado" en la primera mitad del siglo XX o luego con las rondas campesinas en su afán de reinstitucionalizar la hegemonía comunal en nombre del Estado. Destacando la unidad de las memorias y los silencios como producción social y la agencialidad de la misma en relación a contextos históricos y políticos.

Esta investigación es un esfuerzo incalculable por (re)presentar el conflicto armado interno alternativamente, historizando las memorias, debiendo ser emprendido desde diferentes estudios de caso. El afán por el estudio del sentido documental de las imágenes y su articulación con la concepción del mundo, una representación iconológica a decir de Karl Mannheim, estaría en esta misma líneapor (re)pensar comunidades afectadas.

Diego Álvarez 